\title{
Growth and nutrient accumulation in the aerial part of red pitaya (Hylocereus sp.)
}

\author{
Denise de Castro Lima ${ }^{1}$, Nouglas Veloso Barbosa Mendes², \\ Márcio Cleber de Medeiros Corrêa ${ }^{3}$, Carlos Alberto Kenji Taniguchi ${ }^{4}$, \\ Ronialison Fernandes Queiroz ${ }^{5}$,William Natale ${ }^{6}$
}

Abstract - Knowledge on the amounts of nutrients accumulated by pitaya in its different development stages allows defining the periods in which the essential elements are most required, thus contributing to the elaboration of rational fertilization programs for the crop, reducing production costs. This study aimed to evaluate the growth and nutritional requirement of red pitaya, estimating the accumulation of macro and micronutrients by the plants and determining the periods in which the greatest accumulations occur, as well as the relative growth rate and the relative nutrient absorption rate. Pitaya seedlings were planted in pots containing Argissolo Vermelho-Amarelo Eutrófico (Ultisol) and grown in the open air. The experimental design was randomized blocks, with four replicates and seven sampling times: 0, 60, 120, 180, 240, 300 and 360 DAP (days after planting). At each sampling time, length of cladodes, dry matter of the aerial part and nutrient accumulation in the aerial part were evaluated. Red pitaya plants showed a low growth rate until 60 days and, from this period, its growth increased significantly. Nutrient accumulation occurred in the following descending order: $\mathrm{K}>\mathrm{Ca}>\mathrm{N}>\mathrm{Mg}=\mathrm{P}>\mathrm{S}>\mathrm{Na}$ element $>\mathrm{Zn}>\mathrm{Mn}>\mathrm{Fe}>\mathrm{B}$ $>\mathrm{Cu}$. $\mathrm{K}$ and $\mathrm{Zn}$ were, respectively, the most exported macro and micronutrient by pitaya fruits.

Index terms: mineral nutrition, Cactaceae, nutritional requirement.

\section{Crescimento e acúmulo de nutrientes na parte aérea da pitaia vermelha (Hylocereus sp.)}

Corresponding author: dennisedecastro@gmail.com

Received: February 18, 2019 Accepted: September 22, 2019

Copyright: All the contents of this journal, except where otherwise noted, is licensed under a Creative Commons Attribution License.

\begin{abstract}
Resumo - O conhecimento das quantidades de nutrientes acumulados pela pitaia nas diferentes fases de desenvolvimento permite definir as épocas em que os elementos essenciais são mais exigidos, contribuindo assim para a elaboração de programas de adubação racionais para a cultura, diminuindo os custos de produção. Objetivou-se com este trabalho avaliar o crescimento e a demanda nutricional da pitaia vermelha, estimando o acúmulo de macro e micronutrientes pelas plantas e determinando as épocas em que ocorrem os maiores acúmulos, bem como a taxa de crescimento relativo e a taxa de absorção relativa de nutrientes. As mudas de pitaia foram plantadas em vasos contendo um Argissolo Vermelho-Amarelo Eutrófico e conduzidas a céu aberto. O delineamento experimental utilizado foi em blocos casualizados, com quatro repetições e sete épocas de amostragens: 0, 60, 120, 180, 240, 300 e 360 DAP (dias após o plantio). Em cada época de amostragem avaliou-se o comprimento dos cladódios, matéria seca da parte aérea e o acúmulo de nutrientes da parte aérea. As plantas de pitaia vermelha apresentaram baixa taxa de crescimento até 60 dias e, a partir deste período, o crescimento aumentou significativamente. $\mathrm{O}$ acúmulo de nutrientes ocorreu na seguinte ordem decrescente: $\mathrm{K}>\mathrm{Ca}>\mathrm{N}>\mathrm{Mg}=\mathrm{P}>\mathrm{S}>$ elemento $\mathrm{Na}>$ $\mathrm{Zn}>\mathrm{Mn}>\mathrm{Fe}>\mathrm{B}>\mathrm{Cu}$. O K e o $\mathrm{Zn}$ foram, respectivamente, o macro e o micronutriente mais exportados pelos frutos da pitaia.
\end{abstract}

Termos para indexação: nutrição mineral, cactaceae, exigência nutricional.

${ }^{1}$ DSc in Soil Science, Soil Science Department, Federal University of Ceará, Fortaleza-CE, Brazil. E-mail: dennisedecastro@gmail.com ${ }^{\text {(ORCID }}$ 0000-0001-5313-7586)

${ }^{2} \mathrm{MSc}$ in Agronomy-Plant Science, Plant Science Department, Federal University of Ceará, Fortaleza-CE, Brazil. E-mail: nouglasmendes@hotmail. com $^{\text {(ORCID } 0000-0003-4873-3206)}$

${ }^{3}$ DSc in Agronomy-Plant Production, Professor at Undergraduate and Graduate Levels, Plant Science Department, Federal University of Ceará, Fortaleza-CE, Brazil. E-mail: mcleber@ufc.br(ORCID 0000-0002-0702-4959)

${ }^{4}$ DSc in Agronomy-Soil Science, Researcher at Embrapa Agroindústria Tropical/Laboratório de Solos, Fortaleza-CE, Brazil. E-mail: carlos. taniguchi@embrapa.br (ORCID 0000-0002-1280-8678)

${ }^{5}$ DSc in Agronomy-Plant Science, Plant Science Department, Federal University of Ceará, Fortaleza-CE, Brazil. E-mail: ronialison@hotmail. com $^{\text {(ORCID } 0000-0003-1507-7492)}$

${ }^{6}$ DSc in Agronomy-Soils and Plant Nutrition, Senior Visiting Professor, Plant Science Department, Federal University of Ceará, Fortaleza-CE, Brazil. E-mail: natale@ufc.br (ORCID 0000-0001-9572-4463) 


\section{Introduction}

Pitaya is the most cultivated cactus fruit tree in the world (MIZRAHI et al., 1997). It is a perennial plant that usually grows on either trees or rocks, with cladode-type stems, which are modified structures with capacity to perform photosynthesis and accumulate water (SANTOS et al., 2013). Physiologically, it has a specific type of metabolism, called the Crassulacean Acid Metabolism (CAM). Because pitaya has an adaptive metabolism to limiting water conditions, its cultivation is indicated for regions with low precipitation (SILVA, 2014), such as the northeastern semiarid region of Brazil.

Red-skinned, red-fleshed pitaya (Hylocereus sp.) is one of the existing species of pitaya with increasing acceptance in the consumer market (CORDEIRO et al., 2015). The slightly sweet taste, the more attractive flesh color and its functional properties superior to those of other pitaya species (LIMA et al., 2013) make its cultivation promising.

One of the obstacles to increasing the profitable commercial cultivation of pitaya is the lack of information about its nutritional management (COSTA et al., 2015). Studies related to the mineral nutrition of pitaya are still scarce, which leads to empirical fertilizer recommendations for the crop. Hence, it is necessary to conduct studies to determine the amount of nutrients required by pitaya throughout its life cycle, defining the times in which the elements are most required, thus contributing to the elaboration of rational fertilization programs for the crop.

Studying nutrient accumulation as a function of plant age is fundamental because, in addition to defining the most adequate quantities and times for fertilizer application, it contributes to increasing crop management efficiency, promoting gains in yield and reducing production costs through the rational and efficient use of inputs (SOARES et al., 2014).

Given the lack of information on the nutritional requirement of pitaya throughout its cultivation cycle, this study aimed to evaluate the growth and nutritional requirement of red pitaya, estimating the accumulation of macro and micronutrients by plants and determining the times in which the greatest accumulations occur, as well as the relative growth rate and the relative nutrient absorption rate.

\section{Material and methods}

The experiment was carried out in the Agriculture Sector of the Plant Science Department of the Federal University of Ceará, in the municipality of Fortaleza, CE, Brazil, in pots in the open air, from July 2016 to July 2017. The climate of the region is Aw (tropical and with summer rains) according to Köppen's classification
(KOPPEN,1918). The climatological data along the experimental period are presented in Figure 1.

In order to produce pitaya seedlings, healthy cuttings, with mean length of $25 \mathrm{~cm}$, were selected. The cuttings were planted at $3 \mathrm{~cm}$ depth in $3-\mathrm{dm}^{3}$ polyethylene bags, containing arisco (poorly sorted sandy material used in constructions) + coconut fiber in the proportion of $1: 1(\mathrm{v} / \mathrm{v})$, kept in a protected environment for 60 days until rooting, and were subsequently transplanted to polyethylene pots with capacity for $25 \mathrm{dm}^{3}$. The seedlings were transplanted to the pots only with the mother cladode (primary cladode). Then, they were grown in single stem until reaching $1.5 \mathrm{~m}$ height, when their tips were cut to induce the growth of primary lateral cladodes (one cladode to each side). When these cladodes were $40 \mathrm{~cm}$ long, their tips were cut to stimulate the growth of secondary lateral cladodes (three cladodes to each side).

Pitaya is a cactus species that requires a supporting system, and the present experiment used Eucalyptus posts connected by four wires ( $3 \mathrm{~mm}$ diameter) to support the plants at $1.6 \mathrm{~m}$ height. Each pot received one stake made of Quince ( $25 \mathrm{~mm}$ diameter and $1.5 \mathrm{~m}$ height) to guide the plant until it reached the wire.

The soil used to fill the pots was an Argissolo Vermelho-Amarelo Eutrófico (Ultisol), analyzed according to the procedures described in Embrapa (2009), and its chemical characteristics are presented in Table 1.

After soil analysis, soil acidity was corrected with agricultural lime (RNV of 91\%) to increase base saturation to $70 \%$. The amount of lime applied was $0.732 \mathrm{tha}^{-1}$, which corresponded to $9.1 \mathrm{~g} \mathrm{pot}^{-1}$ with 25 kilograms of soil. After lime application, the pots were irrigated and covered with black polyethylene bags for 30 days. After this period, the seedlings were transplanted to polyethylene pots, kept in the open air. The nutrient doses suggested by Almeida et al. (2014) and Corrêa et al. (2014) for pitaya were used, in mg dm${ }^{-3}: 750$ of N, 375 of P, 375 of K and 10 of Zn. The sources used were: urea $(46 \% \mathrm{~N})$, single superphosphate $\left(18 \% \mathrm{P}_{2} \mathrm{O}_{5}, 25 \% \mathrm{CaO}\right.$ and $\left.12 \% \mathrm{~S}\right)$, potassium chloride $\left(62 \% \mathrm{~K}_{2} \mathrm{O}\right)$ and FTE BR-12 (a granulated mixture of micronutrients containing $9 \% \mathrm{Zn}, 1.80 \% \mathrm{~B}, 0.80 \% \mathrm{Cu}$, $2 \% \mathrm{Mn}$ and $0.10 \% \mathrm{Mo}$ ). $120 \mathrm{~g}$ of single superphosphate, $2.8 \mathrm{~g}$ of FTE BR-12, $3.4 \mathrm{~g}$ of urea and $1.6 \mathrm{~g}$ of potassium chloride were applied in each pot.

Single superphosphate and $50 \%$ of the FTE BR-12 dose were applied when the seedlings were transplanted to the pots. The remainder of the FTE BR-12 dose was added at 180 days after pitaya plants were transplanted to the pots. Urea and potassium chloride were solubilized in water ( $50 \mathrm{~mL}$ of water) and applied to the soil surface; nitrogenous and potassium fertilizers were distributed monthly, with applications split into eleven portions. Irrigation was performed manually, three times a week, by applying $1 \mathrm{~L}$ of water per pot, and was suspended at the beginning of the rainy season. 
The experimental design was randomized blocks, with the treatments represented by sampling times $(0$, $60,120,180,240,300$ and 360 days after planting) and four replicates.

The characteristics evaluated at each sampling time were: a) length of cladodes: determined by the sum of all cladodes produced by the plant, except the mother cladode, measured with a tape measure, with results expressed in $\mathrm{cm}$ plant $\left.{ }^{-1} ; \mathbf{b}\right)$ dry matter of the aerial part: the cladodes (main and lateral), floral buds, flowers and fruits were washed, separated, placed in previously identified paper bags, and dried in a forced air circulation oven $\left(65^{\circ} \mathrm{C}\right)$ until constant weight. After drying, the materials of the different plant organs were weighed and then the values of all plant parts were summed to determine the dry matter of the aerial part, with results expressed in g plant $\left.^{-1} ; \mathbf{c}\right)$ accumulation of macro and micronutrients in the aerial part: after determining the contents of nutrients: $\mathrm{N}, \mathrm{P}, \mathrm{K}, \mathrm{Ca}, \mathrm{Mg}, \mathrm{S}, \mathrm{Cu}, \mathrm{Fe}, \mathrm{Zn}, \mathrm{Mn}$ and $\mathrm{B}+\mathrm{Na}$ element, according to the methodology described by Embrapa (2009), the accumulation of macronutrients $\left(\mathrm{g} \mathrm{plant}^{-1}\right)$ and micronutrients $\left(\mathrm{mg} \mathrm{plant}^{-1}\right)$ was determined by multiplying the content of each nutrient in the aerial part by the dry matter of the aerial part; d) quantity of nutrients exported by the fruit: determined by multiplying the content of each nutrient in the fruit by the fruit dry weight, with results expressed in $\mathrm{g}$ fruit $^{-1}$.

The obtained data were subjected to analysis of variance, and the logistic model was fitted to the means of almost all nutrients. The logistic model of three parameters, described by Nelder (1961), represented by the equation below, was used:

$$
Y=\frac{a}{1+b * e^{(-c X)}}
$$

where: $Y=$ dependent variable; $a=$ asymptotic parameter (maximum growth or accumulation); $e=$ inverse of the natural logarithm; $b=$ location parameter; $c=$ maturity rate (indicates growth velocity to reach the asymptotic value) and $X=$ time. The statistical program SAS (SAS, 2012) was used. Figures were created using the program Sigma Plot version 11.0 (SYSTAT SOFTWARE, 2006).

In addition, the relative growth rate (RGR) and the relative nutrient absorption rate (RNAR) were also determined according to the equation of Welbank (1962):

$$
R G R=\frac{\left(\ln M_{2}-\ln M_{1}\right)}{\left(t_{2}-t_{1}\right)}
$$

where: RGR: relative growth rate, in $\mathrm{g} \mathrm{g}^{-1}$ day $^{-1} ; \ln$ - natural logarithm; $M_{1}$ and $M_{2}$ : dry matter of the organ or plant, in g plant $^{-1}$, referring to the times $t_{1}$ and $t_{2}$, respectively; $t_{1}$ and $t_{2}$ : time interval between evaluations, in days.

$$
\text { RNAR }=\frac{\left(N_{2}-N_{1}\right)\left(\ln M_{2}-\ln M_{1}\right)}{\left(t_{2}-t_{1}\right)\left(M_{2}-M_{1}\right)}
$$

where: RNAR: relative nutrient absorption rate, in $\mathrm{mg} \mathrm{g}^{-1}$ day $^{-1}$ and $\mu \mathrm{g} \mathrm{g}^{-1}$ day $^{-1} ; \mathrm{N}_{1}$ and $\mathrm{N}_{2}$ : quantities of nutrient in the plant organ referring to the times $t_{1}$ and $\mathrm{t}_{2}$, respectively; ln -natural logarithm; $\mathrm{M}_{1}$ and $\mathrm{M}_{2}$ : total dry matter of the plant referring to the times $t_{1}$ and $t_{2}$, respectively; $t_{1}$ and $t_{2}$ : time interval between evaluations.

\section{Results and discussion}

The initial growth of pitaya plants was characterized by a slight increment in the length of cladodes until $60 \mathrm{DAP}$, with daily rates of $0.36 \mathrm{~cm}$ plant ${ }^{-1}$. From 61 to 240 DAP, the daily growth rate of the cladodes was $1.91 \mathrm{~cm}$ plant $^{-1}$ and, from 241 to 360 DAP, their daily growth rate was $0.67 \mathrm{~cm}$ plant $^{-1}$. At 360 days, the sum of the lengths of pitaya cladodes was $455.13 \mathrm{~cm}_{\text {plant }}{ }^{-1}$ (FIGURE 2A), a result higher than that observed by Ferrari et al. (2017), when evaluating the growth of pitaya plants from different numbers of cladodes per hole.

It can be observed with these results that the growth of pitaya cladodes is slow until 60 days (FIGURE 2A), which is probably due to the small size of the plants in this period because, according to Lima Filho (1995), the growth rate is proportional to the size of the individual. From 61 to 240 days, there was a more vigorous growth of the cladodes (FIGURE 2A), characterized by great development of the main cladode and emergence of lateral cladodes. From 240 days, there was a reduction in cladode growth rate (FIGURE 2A), probably due to the change in plant development stage, from vegetative stage to reproductive stage.

The total dry matter accumulation in the aerial part (cladodes, flowers and fruits) by pitaya plants increased slightly until 60 days, with daily accumulation of $0.25 \mathrm{~g} \mathrm{plant}^{-1}$. The daily accumulation rate was equal to $0.90 \mathrm{~g} \mathrm{plant}^{-1}$ from 60 to 180 days and to $1.42 \mathrm{~g} \mathrm{plant}^{-1}$ day $^{-1}$ from 180 to 360 days. The maximum estimated production of dry matter in the aerial part occurred at the end of the experimental period, 360 days, and was equal to $388.44 \mathrm{~g} \mathrm{plant}^{-1}$ (FIGURE 2B). Analyzing the growth and production of "Vitória" pineapple irrigated under semiarid conditions, Pegoraro et al. (2014a) observed a pattern of total dry matter accumulation similar to that observed in the present study with pitaya. Although it is not part of the cactus family, pineapple is a species that has a root system similar to that of pitaya (FERNANDES, 2016) and the same type of metabolism, the Crassulacean Acid Metabolism (CAM). 
In order to facilitate the nutritional management of pitaya, the present study recommends dividing the cycle into three phenological stages, defined from the total dry matter accumulation in the aerial part. The first vegetative stage (V1) starts between 0 and 60 days, characterized by slow dry matter accumulation; at this stage, the plants accumulated only $6.1 \%$ of the total dry matter produced (FIGURE 2B). In this initial phase of cultivation, the growth of the main cladode is slow and, consequently, there is low biomass production. The second vegetative stage (V2), from 60 to 180 days, is represented by the rapid accumulation of dry matter, which is justified by the higher growth of cladodes and, therefore, higher biomass production; at this stage, the main cladode and lateral cladodes contribute with $34.1 \%$ of the total dry matter produced (FIGURE 2B). The third stage, reproductive (R), occurs between 180 and 360 days; at this stage, dry matter accumulation continues to increase and the cladodes (main and lateral), floral buds, flowers and fruits began to contribute more intensely to the total dry matter accumulation, representing $59.8 \%$ of the total dry matter accumulated (FIGURE 2B).

Regarding the reproductive stage of pitaya, it was observed that the production of floral buds and flowers began between 180 and 240 days (January to March). Fruit production began at 240 days, with higher intensity in the period from 240 to 300 days (March to May). The early production of the plants demonstrates a satisfactory response to the experimental conditions. In the first year, as in the case of this study, pitaya is still in the phase of formation, producing structural and productive cladodes, which may lead to low fruit production.

It was found that the reproductive stage of pitaya occurs in periods of higher precipitation (FIGURE 1), and this result is similar to that obtained by MUNIZ (2017), SILVA et al. (2015) and MARQUES et al. (2011) in pitaya plants. Evaluating the correlation between environmental factors and the reproductive period of pitaya (Hylocereus undatus) in Lavras-MG, Marques et al. (2010) observed that temperature, relative humidity and precipitation are the climatic variables that most interfere with pitaya phenology. According to the authors, the highest number of flowers occurs in the months of lower insolation, which can be attributed to the characteristic of the species, as it is adapted to a typical forest climate. Flowering, in response to environmental stimuli, ensures that seeds are produced under favorable conditions, particularly in response to water and temperature (TAIZ et al., 2017).

At the end of the experimental period (360 days), the accumulation of macronutrients in the total dry matter of the aerial part (cladodes, flowers and fruits) of pitaya occurred in the following descending order: $\mathrm{K}>\mathrm{Ca}>\mathrm{N}>$ $\mathrm{P}>\mathrm{Mg}>\mathrm{S}$. These results show that potassium and calcium were the most required nutrients by red pitaya (FIGURE $3 \mathrm{~A})$. This order of nutrient accumulation differed from that observed by Diógenes (2017), who reported the following order in the accumulation of macronutrients in the aerial part of another species of pitaya (Hylocereus undatus): $\mathrm{K}>\mathrm{N}>\mathrm{Ca}>\mathrm{Mg}>\mathrm{P}>\mathrm{S}$. According to Rozane et al. (2011), variations in nutrient accumulation can occur when different genetic materials and growing media are employed.

In general, the accumulation of macronutrients by pitaya was slow until $60 \mathrm{DAP}$, which is due to the low dry matter production in this period (FIGURES 3A and $2 \mathrm{~B}$ ); however, after this period, there was a marked increase in the accumulation of macronutrients in the aerial part. Pitaya plants showed different periods of maximum macronutrient accumulation (FIGURE 3A).

$\mathrm{K}, \mathrm{Ca}$ and $\mathrm{P}$, respectively the first, second and fourth most accumulated macronutrient by the aerial part of pitaya, had maximum accumulation rates in the period from 180 to 240 days. The maximum accumulation of these nutrients occurs at the beginning of the reproductive stage, which is hence considered the period of highest demand by pitaya (FIGURE 3A). The maximum accumulation rates for $\mathrm{K}, \mathrm{Ca}$ and $\mathrm{P}$ were: $0.034,0.033$ and $0.008 \mathrm{~g}$ plant $^{-1}$ day $^{-1}$, respectively (FIGURE 3A). After 360 days, the maximum accumulation of potassium, calcium and phosphorus was: $7.79,6.78$ and $1.82 \mathrm{~g} \mathrm{plant}^{-1}$, respectively. These values are higher than those observed by Moreira et al. (2016), but these authors worked with another species of pitaya. Moreover, the experimental period was shorter and did not include flowers and fruits in the evaluation, which may justify the differences observed compared to the present study.

$\mathrm{K}$ was the most required macronutrient by pitaya (FIGURE 3A), so supplying this nutrient throughout the crop cycle is essential. Despite not being part of the structure of any organic compound, K performs important functions in plants, such as in the stomatal opening and closing, translocation of sugars, photosynthesis, osmotic regulation, among others (MALAVOLTA, 2006). The quality of agricultural products and high yields are directly related to the contribution of K to crops (MALAVOLTA, 2006).

The increasing accumulation of $\mathrm{Ca}$ until 360 days (FIGURE 3A) may be related to its low mobility in the phloem, with no redistribution from the cladodes to other organs (MALAVOLTA, 2006) such as inflorescences and fruits. Thus, it is believed that the older the plant, the greater the amount of $\mathrm{Ca}$. When evaluating the chemical and mineral composition of cactus species in the semiarid region of Paraíba, Germano et al. (1999) observed that $\mathrm{Ca}$ content tends to increase with plant age.

The greater accumulation of $\mathrm{P}$ during the reproductive stage is probably due to its importance in the formation of the primordia of reproductive parts, so its application is essential for good formation of seeds and fruits (RAIJ, 1991). With respect to N, the third most 
accumulated macronutrient by pitaya, the maximum accumulation rate was $0.028 \mathrm{~g} \mathrm{plant}^{-1} \mathrm{day}^{-1}$, obtained in the period between 120 and 180 days (FIGURE 3A), which coincides with the highest growth of cladodes (FIGURE 2A). According to Luders and McMahon (2006), N stimulates the production of roots and shoots, being required during the vegetative growth until the preflowering of pitaya.

The least required macronutrients were $\mathrm{Mg}$ and $\mathrm{S}$; both had maximum accumulation rate in the period between 120 and 180 days, with daily accumulations of 0.010 and 0.008 g plant $^{-1}$ of $\mathrm{Mg}$ and $\mathrm{S}$, respectively. $\mathrm{Mg}$ acts in the structural composition of the chlorophyll molecule and, depending on the "status" of $\mathrm{Mg}$ in the plant, about 6 to $25 \%$ of the total Mg may be bound to the chlorophyll molecule, while 5 to $10 \%$ would be either bound to pectates in the cell wall or deposited as soluble salts in the vacuole (MARSCHNER, 2012). The total accumulation of $\mathrm{Mg}$ and $\mathrm{S}$ at the end of the experimental period was: 1.65 and $0.97 \mathrm{~g} \mathrm{plant}^{-1}$, respectively (FIGURE $3 \mathrm{~A})$. Sulfur requirement for good plant growth varies from 0.1 to $0.5 \%$ of dry weight (MARSCHNER, 2012). Thus, the total sulfur accumulation observed in the aerial part of pitaya is within the range considered normal.

In relation to the $\mathrm{Na}$ element, there was an accumulation of $0.360 \mathrm{~g} \mathrm{plant}^{-1}$ at 360 days, with maximum accumulation rate of $0.002 \mathrm{~g} \mathrm{plant}^{-1}$ day $^{-1}$ in the period from 120 to 180 days (FIGURE 3A). Na is important for species that use the CAM pathway for carbon fixation, such as pitaya, employing this element in the regeneration of phosphoenolpyruvate (TAIZ et al., 2017). $\mathrm{Na}$ is absorbed by plants in its ionic form, $\mathrm{Na}^{+}$, and has high mobility in plant tissues, with concentration varying between 0.013 and $35.1 \mathrm{~g} \mathrm{~kg}^{-1}$ in the dry matter of the aerial part (INOCÊNCIO et al., 2014).

For the micronutrients, it was observed that $\mathrm{Zn}$, $\mathrm{Mn}$ and $\mathrm{Fe}$ were the most accumulated by the aerial part of pitaya, in this sequence, which is not consistent with the order reported by Moreira et al. (2016), who found the order of $\mathrm{Mn}, \mathrm{Fe}$ and $\mathrm{Zn}$ in white pitaya (Hylocereus undatus). These differences in the order of accumulation may be due to the differences in genetic material and the different conditions of cultivation, justifying the need for more specific studies on pitaya growth and nutrient accumulation. The accumulation of $\mathrm{Zn}$ in the aerial part of red pitaya was $42.39 \mathrm{mg} \mathrm{plant}^{-1}$ at 360 days, and the demand for this element increases from 180 days, i.e., at the beginning of the reproductive stage (FIGURE 3B). As $\mathrm{Zn}$ is an activator of several enzymes and precursor in the formation of auxins (TAIZ et al., 2017), this increase in $\mathrm{Zn}$ requirement may be related to the synthesis of these compounds needed for the formation of flowers and fruits.

For Mn, the period between 180 and 240 days had the highest accumulation, with maximum rate of $0.180 \mathrm{mg}$ plant $^{-1}$ day $^{-1}$ and total accumulation, at 360 days, of 29.68 mg plant ${ }^{-1}$ (FIGURE 3B). The maximum Fe accumulation rate was obtained from 300 to 360 days, $0.152 \mathrm{mg}$ plant $^{-1}$ day $^{-1}$ (FIGURE 3B), with maximum accumulation of $27.0 \mathrm{~g} \mathrm{plant}^{-1}$. Diógenes (2017), working with white pitaya, found $\mathrm{Mn}$ accumulation of $4.2 \mathrm{mg} \mathrm{plant}^{-1}$ and $\mathrm{Fe}$ accumulation of $4.8 \mathrm{mg} \mathrm{plant}^{-1}$ at 195 DAP. As they act as enzyme activators in the photosynthetic process, $\mathrm{Mn}$ and $\mathrm{Fe}$ are nutrients of extreme importance for plants (CRISÓSTOMO; NAUMOV, 2009, PRADO, 2008).

$\mathrm{B}$ and $\mathrm{Cu}$ were the least accumulated micronutrients by the aerial part of pitaya, with maximum accumulations of $6.80 \mathrm{mg}$ plant $^{-1}$ and $2.45 \mathrm{mg}$ plant $^{-1}$, respectively, at 360 days. The highest $\mathrm{B}$ accumulation occurred in the period between 180 and 240 days, with maximum accumulation rate of $0.042 \mathrm{mg} \mathrm{plant}^{-1}$ day $^{-1}$ (Figure 3B). It was observed that the requirement of $\mathrm{B}$ by pitaya is higher during the reproductive stage. According to Malavolta (2006), in many plants the requirements of $\mathrm{B}$ in the reproductive stage is much higher than those during the vegetative growth, because B influences pollen grain germination and pollen tube growth.

In the pitaya crop, fruits constitute the main route for nutrient export. Nutrient export by the fruits occurred in the following descending order: $\mathrm{K}>\mathrm{N}>\mathrm{P}=\mathrm{Mg}>\mathrm{Ca}$ $>\mathrm{S}>\mathrm{Na}$ element $>\mathrm{Zn}>\mathrm{B}>\mathrm{Fe}>\mathrm{Mn}>\mathrm{Cu}$ (FIGURE 4). Almeida et al. (2009) observed that $\mathrm{K}$ is the most abundant nutrient in tropical fruits cultivated in northeastern Brazil. $\mathrm{K}$ and $\mathrm{Zn}$ were, respectively, the most exported macro and micronutrient by pitaya fruits (FIGURE 4). The greater amount of $\mathrm{K}$ exported by the fruits compared to the other nutrients is possibly due to the role played by this nutrient in the transport of soluble solids, as well as in the maintenance of the high water content of the fruit (MARSCHNER, 2012).

It is estimated that $19.1 \%, 13.6 \%, 7.1 \%, 1.4 \%$, $7.8 \%, 6.1 \%, 8.3 \%, 5.6 \%, 25.8 \%, 3.7 \%, 2.55 \%$ and $10.2 \%$ of the total K, N, P, Ca, Mg, S, Na element, Zn, B, Fe, $\mathrm{Mn}$ and $\mathrm{Cu}$ absorbed, respectively, are exported by the harvest (FIGURES 3 and 4). No information is found in the literature on nutrient exportation by pitaya fruits. Despite the low fruit production obtained in the present study, the preliminary results observed for nutrient export are extremely important due to the scarcity of information on this subject.

The RGR measures the increase of dry matter per unit of biomass already existing, within a given time interval. For red pitaya, there is higher relative growth in the period from 0 to 60 days $\left(0.043 \mathrm{~g} \mathrm{~g}^{-1}\right.$ day $\left.^{-1}\right)$, with subsequent reduction of RGR until 360 days (TABLE 2). According to Hunt (2003), as the plant grows there is an increase in the proportion of its biomass accumulated in support and reproductive structures, reducing the increment of dry matter per existing unit. 
The RNAR for red pitaya varied according to the nutrient and sampling time. However, in general, higher RNAR occurred between 0 and 60 days (TABLE 3 ). Rozane et al. (2013) observed that the highest RNAR values are observed in the initial periods of the evaluations, due to the low dry matter accumulations observed in this phase, which in the quotient of the formula shows higher nutrient contents and, therefore, higher RNAR.
The RNAR depends on the biomass produced and on an internal factor of plant metabolism linked to its physiological needs for the element, in a given period of development, for a particular tissue or organ (LIMAFILHO et al., 1997). This nutritional index determines the amount of nutrient accumulated as a function of the preexisting biomass. RNAR determination is important for fruit seedlings that are vegetatively propagated by cuttings, as is the case of pitaya, because the seedlings already have sufficient biomass, at the time of transplantation, to obtain the relative nutrient absorption rate (PRADO; FRANCO, 2007).

Table 1. Initial chemical attributes of the soil used to fill the experimental pots

\begin{tabular}{|c|c|c|c|c|c|c|c|c|c|c|c|c|c|c|c|c|}
\hline $\mathrm{P}$ & OM & $\mathrm{pH}$ & $\mathrm{K}^{+}$ & $\mathrm{Ca}^{2+}$ & $\mathrm{Mg}^{2+}$ & $\mathrm{Na}^{+}$ & $\mathrm{H}+\mathrm{Al}$ & $\mathrm{Al}^{3+}$ & SB & $\mathrm{T}$ & V & $\mathrm{Cu}$ & $\mathrm{Fe}$ & $\mathrm{Zn}$ & $\mathrm{Mn}$ & B \\
\hline $\mathrm{mg} \mathrm{dm}-3$ & $\mathrm{~g} \mathrm{~kg}^{-1}$ & & & & o & $\mathrm{mmol}$ & $\mathrm{dm}^{-3}--$ & & & & $\%$ & & 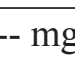 & & & \\
\hline 4.0 & 13.9 & 5.5 & 2.1 & 8.4 & 5.2 & 2.0 & 17.3 & 1.5 & 17.8 & 35.1 & 51.0 & 0.2 & 40.0 & 0.1 & 3.6 & 0.3 \\
\hline
\end{tabular}

$\mathrm{OM}=$ organic matter; $\mathrm{pH}$ in water; $\mathrm{P}, \mathrm{Na}$ and $\mathrm{K}$, Mehlich-1 extractor; $\mathrm{Ca}, \mathrm{Mg}$ and $\mathrm{Al}, \mathrm{KCl}$ extractor; $\mathrm{H}+\mathrm{Al}$, calcium acetate extractor; $\mathrm{SB}=$ sum of exchangeable bases; $\mathrm{T}=$ cation exchange capacity at $\mathrm{pH} 7.0 ; \mathrm{V}=$ base saturation; $\mathrm{Cu}, \mathrm{Zn}, \mathrm{Mn}$ and Fe, DTPA extractor; $\mathrm{B}, \mathrm{HCl}$ extractor.

Table 2. Relative growth rate (RGR) of the aerial part of red pitaya. Fortaleza - CE, 2018

\begin{tabular}{cc}
\hline Period & $\begin{array}{c}\text { Red pitaya } \\
(\text { Whole plant })\end{array}$ \\
\hline Days & $\mathrm{g} \mathrm{g}^{-1}$ day \\
\hline $0-60$ & 0.043 \\
$60-120$ & 0.029 \\
$120-180$ & 0.008 \\
$180-240$ & 0.012 \\
$240-300$ & 0.004 \\
$300-360$ & 0.003 \\
\hline
\end{tabular}

Table 3. Relative nutrient absorption rate (RNAR) of the aerial part of red pitaya. Fortaleza - CE, 2018

\begin{tabular}{|c|c|c|c|c|c|c|c|c|c|c|c|c|}
\hline \multicolumn{13}{|c|}{ Red pitaya(Whole plant) } \\
\hline Periods & $\mathrm{N}$ & $\mathrm{P}$ & K & $\mathrm{Ca}$ & $\mathrm{Mg}$ & $\mathrm{S}$ & $\mathrm{Na}$ & $\mathrm{Cu}$ & $\mathrm{Fe}$ & $\mathrm{Zn}$ & $\mathrm{Mn}$ & $\mathrm{B}$ \\
\hline Days & & & $\ldots \ldots$. & $\mathrm{g} \mathrm{g}^{-1} \mathrm{c}$ & & & & & $\ldots \mu \mathrm{g}$ & ${ }^{-1}$ day $^{-1}$ & & \\
\hline $0-60$ & 1.15 & 0.23 & 1.45 & 0.53 & 0.30 & 0.07 & 0.03 & 0.16 & 1.75 & 1.09 & 3.33 & 0.96 \\
\hline $60-120$ & 0.83 & 0.16 & 0.94 & 0.44 & 0.27 & 0.09 & 0.05 & 0.18 & 0.89 & 0.77 & 1.84 & 0.71 \\
\hline $120-180$ & 0.17 & 0.03 & 0.18 & 0.18 & 0.07 & 0.09 & 0.02 & 0.01 & 1.03 & 0.39 & 1.00 & 0.13 \\
\hline $180-240$ & 0.16 & 0.08 & 0.23 & 0.22 & 0.06 & 0.00 & 0.01 & 0.10 & 1.03 & 1.38 & 1.39 & 0.40 \\
\hline $240-300$ & 0.00 & 0.00 & 0.05 & 0.07 & 0.00 & 0.03 & 0.00 & 0.00 & 0.00 & 0.17 & 0.00 & 0.01 \\
\hline $300-360$ & 0.01 & 0.03 & 0.05 & 0.06 & 0.01 & 0.00 & 0.01 & 0.06 & 0.84 & 1.39 & 0.31 & 0.00 \\
\hline
\end{tabular}



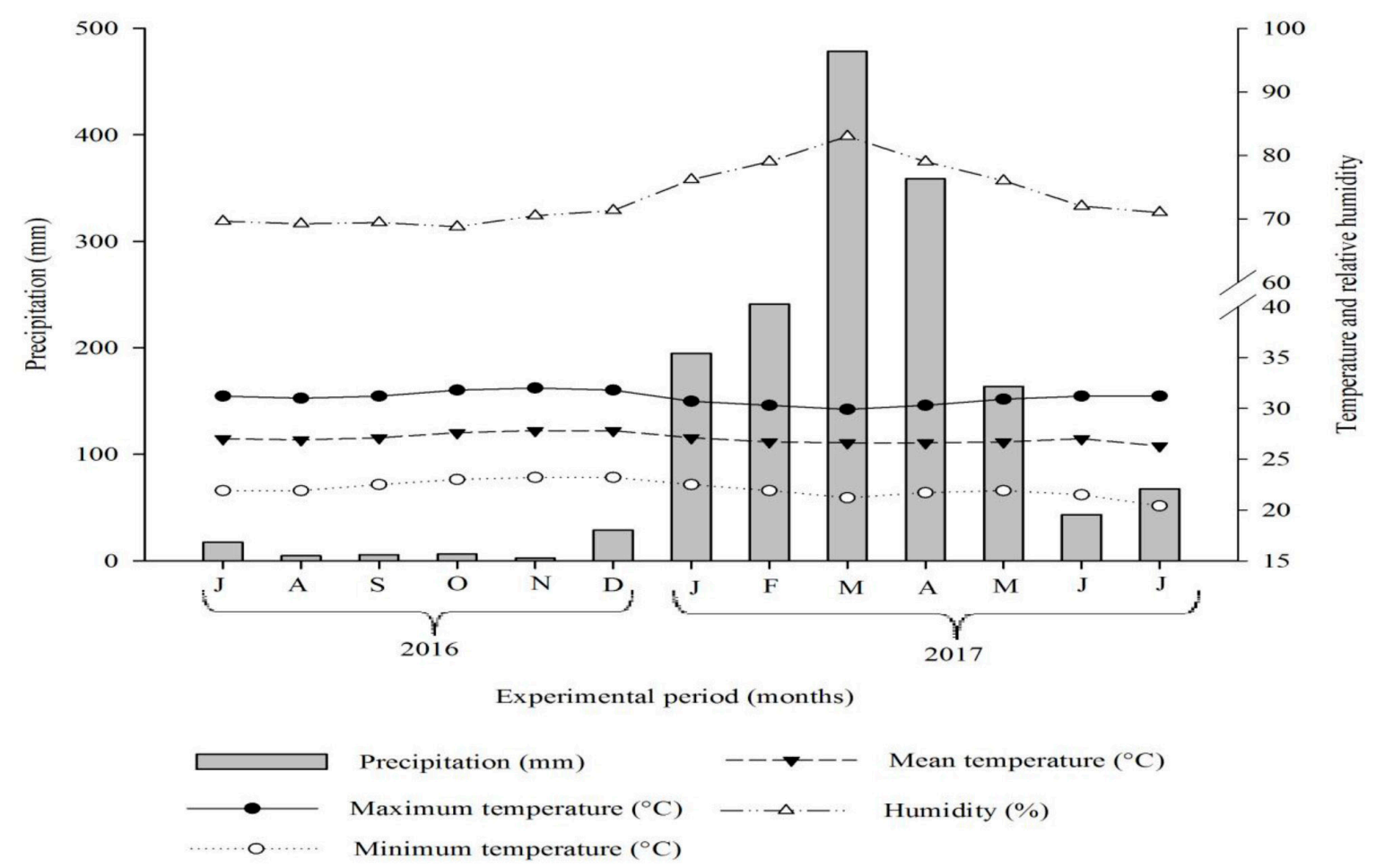

Figure 1. Monthly values of precipitation $(\mathrm{mm})$, maximum temperature $\left({ }^{\circ} \mathrm{C}\right)$, mean temperature $\left({ }^{\circ} \mathrm{C}\right)$, minimum temperature $\left({ }^{\circ} \mathrm{C}\right)$ and relative humidity $(\%)$ along the experimental period in Fortaleza - CE.
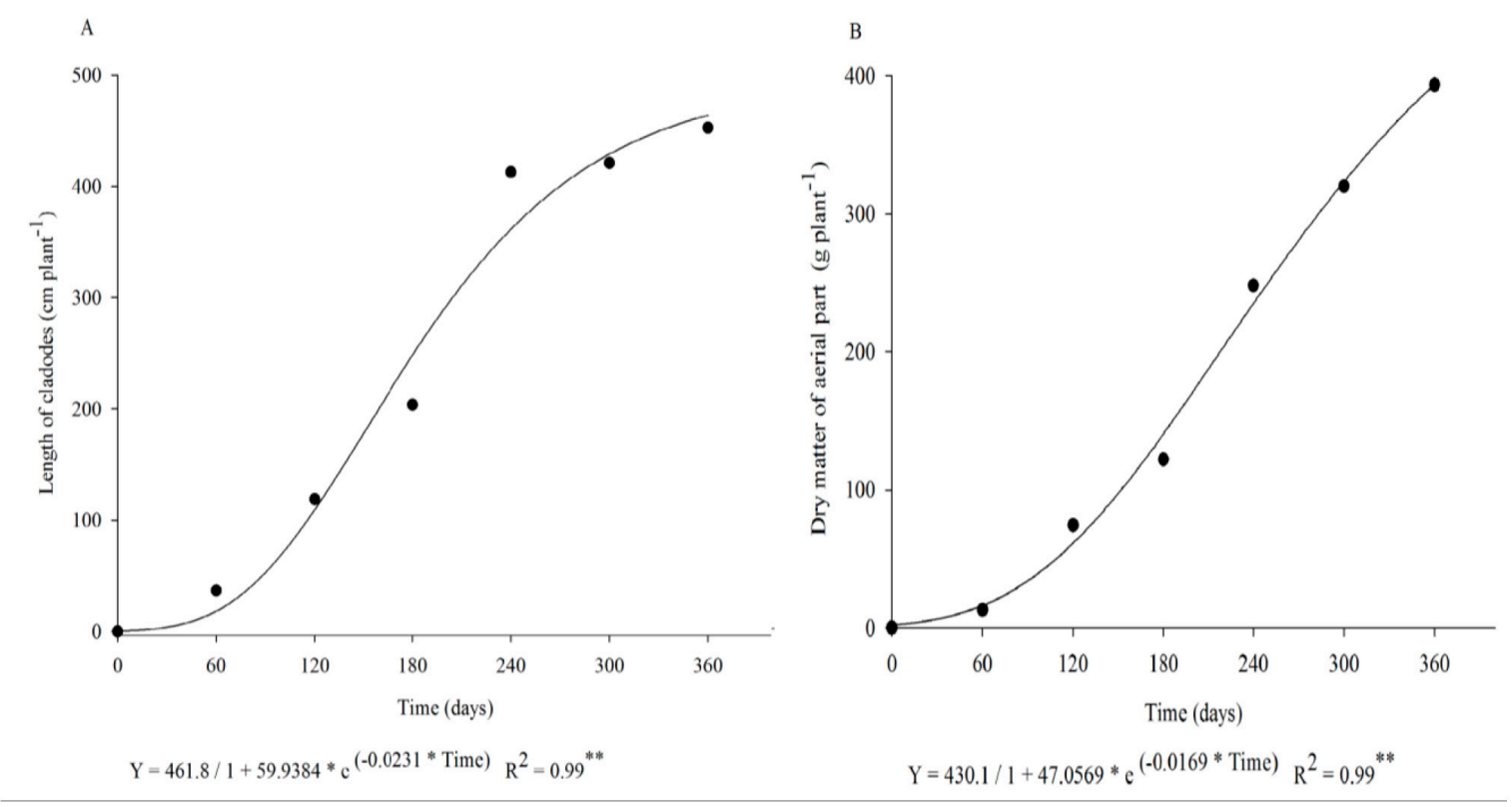

Figure 2. Length of cladodes (A) and dry matter of the aerial part (B) of red pitaya, as a function of the sampling times. Fortaleza, 2018. 

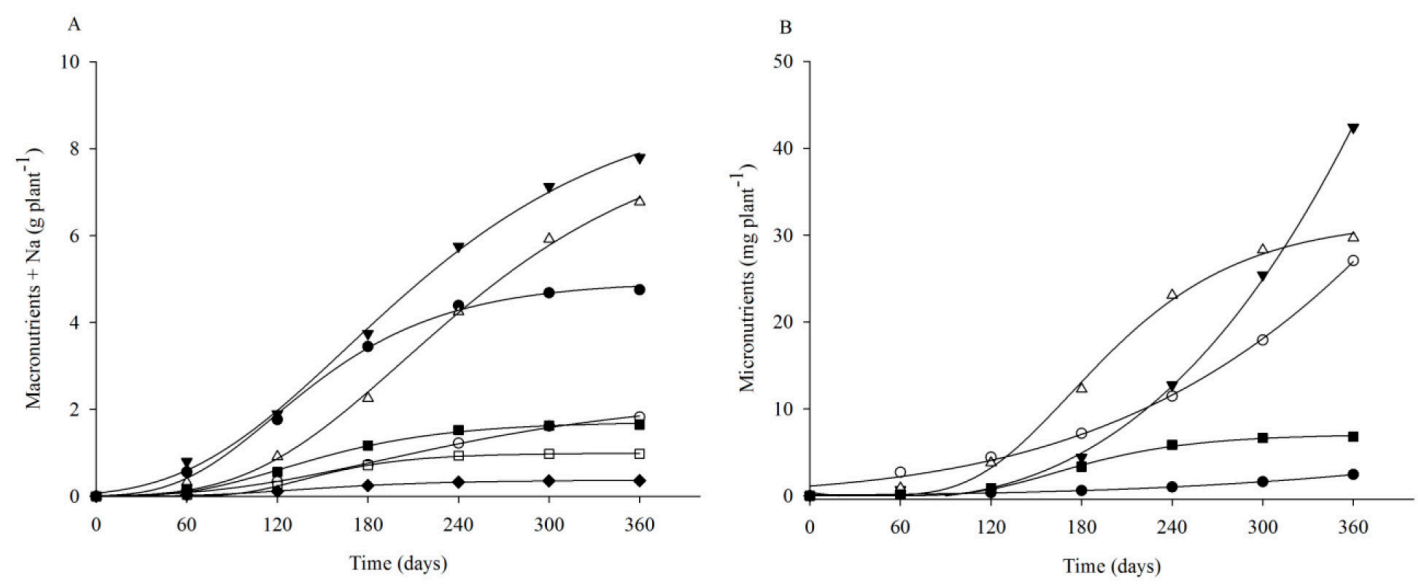

- $\mathrm{N}=4.7725 / 1+33.5133 * \mathrm{e}^{(-0.0248 * \text { Time })} \mathrm{R}^{2}=0.98^{* * *}$

- $\mathrm{Cu}=7.9377 / 1+65.3522 * \mathrm{e}^{(-0.00937 * \text { Time })} \mathrm{R}^{2}=0.92^{* *}$

○ $\mathrm{Fe}=119.5000 / 1+71.5666 * \mathrm{e}^{(-0.0084 * \text { Time })} \mathrm{R}^{2}=0.89 * *$

- $\mathrm{P}=1.9604 / 1+38.4021 * \mathrm{e}^{(-0.0173 * \text { Time })} \quad \mathrm{R}^{2}=0.95$ **

> $\mathrm{K}=8.2192 / 1+25.9761 * \mathrm{e}^{(-0.0171 * \text { Time })} \quad \mathrm{R}^{2}=0.97 * *$

$\Delta \mathrm{Ca}=7.2690 / 1+68.0205 * \mathrm{e}^{(-0.0190 * \text { Time })} \mathrm{R}^{2}=0.98$ **

- $\mathrm{Mg}=1.6558 / 1+43.5585 * \mathrm{e}^{(-0.0258 * \text { Time })} \mathrm{R}^{2}=0.98 * *$

> $\mathrm{Zn}=0.0006 \mathrm{x}^{2}-0.1130 \mathrm{x}+5.3170 \quad \mathrm{R}^{2}=0.99^{* *}$

$\triangle \mathrm{Mn}=30.0730 / 1+159.1000 * \mathrm{e}^{(-0.0261 * \text { Time })} \mathrm{R}^{2}=0.96^{* *}$

- $\mathrm{B}=6.8284 / 1+272.7000 * \mathrm{e}^{(-0.0309 * \text { Time })} \quad \mathrm{R}^{2}=0.96{ }^{* *}$

口 $\mathrm{S}=0.9773 / 1+215,1000 * \mathrm{e}^{(-0.0325 * \text { Time })} \mathrm{R}^{2}=0.94^{* *}$

- $\mathrm{Na}=0.3616 / 1+51.1363 * \mathrm{e}^{(-0.0262 * \text { Time })} \mathrm{R}^{2}=0,97^{* *}$

Figure 3. Accumulation of macronutrients $+\mathrm{Na}(\mathrm{A})$ and micronutrients $(\mathrm{B})$ in the aerial part of red pitaya, as a function of the sampling times. Fortaleza, 2018.
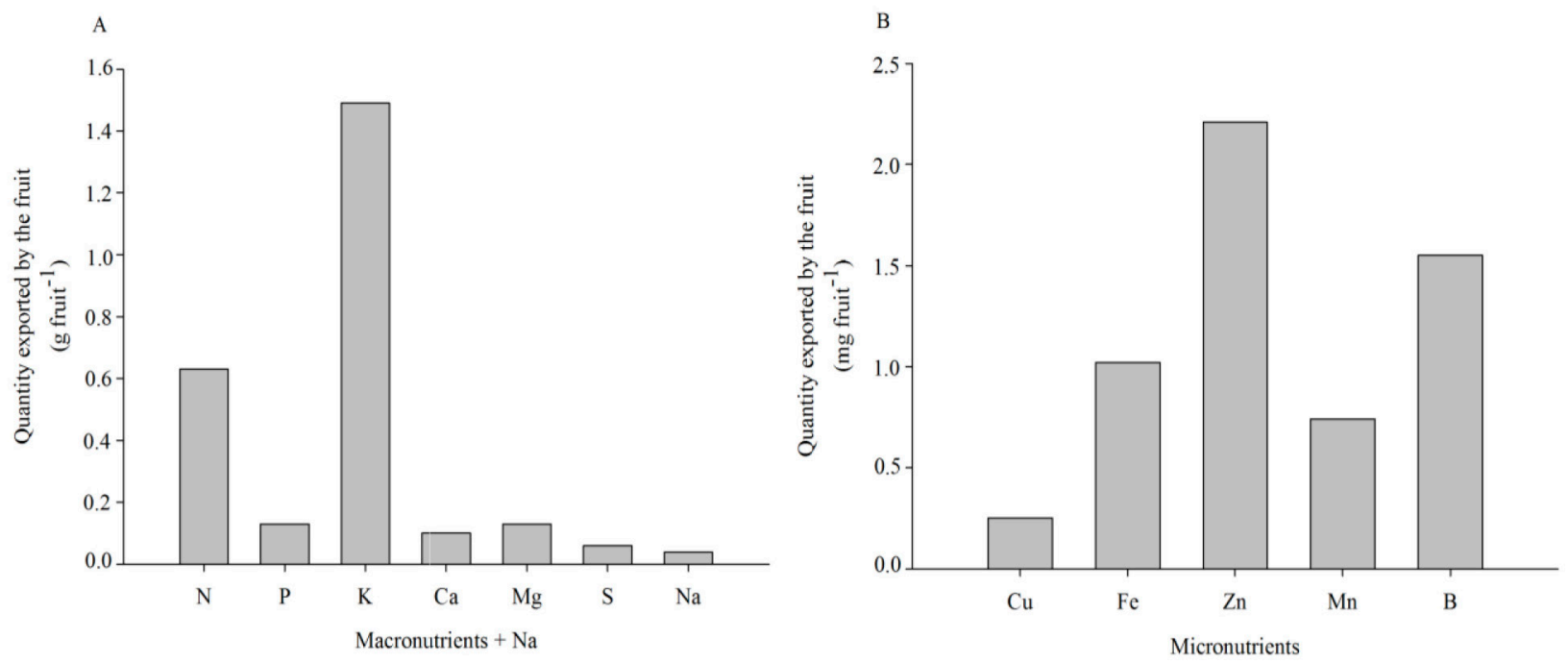

Figure 4. Macronutrients $+\mathrm{Na}$ (A) and micronutrients (B) exported by the fruits of red pitaya. Fortaleza, 2018. 


\section{Conclusions}

Red pitaya plants showed low growth rate until 60 days and, from this period, their growth increased significantly.

Nutrient accumulation in the aerial part occurred in the following descending order: $\mathrm{K}>\mathrm{Ca}>\mathrm{N}>\mathrm{Mg}=\mathrm{P}$ $>\mathrm{S}>(\mathrm{Na}$ element $)>\mathrm{Zn}>\mathrm{Mn}>\mathrm{Fe}>\mathrm{B}>\mathrm{Cu}$.

The highest requirements of $\mathrm{P}, \mathrm{K}, \mathrm{Ca}, \mathrm{Mn}$ and B occurred in the period of 180-240 days after planting; $\mathrm{N}, \mathrm{Mg}, \mathrm{S}$ and $\mathrm{Na}$ element were more required between 120 and 180 days, while $\mathrm{Zn}$ had higher demand between 300 and 360 days; $\mathrm{Cu}$ and $\mathrm{Fe}$ showed constant demands throughout the experiment.

Nutrient export by the fruits occurred in the following descending order $\mathrm{K}>\mathrm{N}>\mathrm{P}=\mathrm{Mg}>\mathrm{Ca}>\mathrm{S}>$ $\mathrm{Na}$ element $>\mathrm{Zn}>\mathrm{B}>\mathrm{Fe}>\mathrm{Mn}>\mathrm{Cu}$

RGR and RNAR values were higher between 0 and 60 days.

\section{Acknowledgments}

To Funcap for granting the scholarship to the first author.

\section{References}

ALMEIDA, E.I.B.; CORREA, M.C.M.; CRISOSTOMO, L.A.; ARAÚJO, N.A.; VALE, J.C. Nitrogênio e potássio no crescimento de mudas de pitaia. Revista Brasileira de Fruticultura, Jaboticabal, v.36, n.4, p.1015-1024, 2014.

ALMEIDA, M.M.B.; SOUSA, P.H.M.; FONSECA, M.L.; MAGALHÃES, C.E.C.; LOPES, M.F.G.; LEMOS, T.L.G. Avaliação de macro e microminerais em frutas tropicais cultivadas no nordeste brasileiro. Ciência e Tecnologia de Alimentos, Campinas, v.29, n.3, p.581- 586, 2009.

CORDEIRO, M.H.M.; PINHEIRO, J.M.S.; MIZOBUTSI, G.P.; MIZOBUTSI, E.H.; MOTA, W.F. Caracterização física, química e nutricional da pitaia-rosa de polpa vermelha. Revista Brasileira de Fruticultura, Jaboticabal, v.37, n.1, p. 20-26, 2015.

CORRÊA, M.C.M.; ALMEIDA, E.I.B.; MARQUES, V.B.; SILVA, J.C.V.; AQUINO, B.F. Crescimento inicial de pitaia em função de combinações de doses de fósforozinco. Revista Brasileira de Fruticultura, Jaboticabal, v.36, n.1, p.261-270, 2014.
COSTA, A.C.; RAMOS, J.D.; SILVA, F.O.R.; MENEZES, T.P.; MOREIRA, R.A.; DUARTE, M.H. Adubação orgânica e Lithothamnium no cultivo da pitaia vermelha. Semina, Londrina, v. 36, n.1, p. 77-87, 2015.

CRISÓSTOMO, L. A.; NAUMOV, A. Adubando para alta produtividade e qualidade: fruteiras tropicais do Brasil. Fortaleza: Embrapa Agroindústria Tropical, 2009. $238 \mathrm{p}$.

DIÓGENES, M.F.S. Curva de crescimento e marcha de absorção de nutrientes da pitaia (Hylocereus undatus). 2017. Trabalho de Conclusão de Curso (Bacharelado em Agronomia) - Universidade Federal do Ceará, Fortaleza, 2017.

EMBRAPA - Empresa Brasileira de Pesquisa Agropecuária. Manual de análises químicas de solos, plantas e fertilizantes. 2.ed. Brasília, DF: Embrapa Informação Tecnológica, 2009. 627p.

FERNANDES, D.N. Adubação fosfatada e potássica no cultivo de pitaia. 2016. Dissertação (Mestrado em Produção Vegetal) - Universidade Federal dos Vales de Jequitinhonha e Mucuri, Diamantina, 2016.

FERRARI, L.L.; PELUZIO, R.M.; CONTARINE, M.A.; TOSTA, J.S.V.; PELUZIO, T.M.O.; HARTUNG L.; SALUCI, J.C.G.; SILVA, A.M.; SILVA, M.M.; PELUZIO, J.B.E. Crescimento de plantas de pitaya a partir de cladódios diretamente no campo e a pleno sol. In: ENCONTRO LATINO AMERICANO DE INICIAÇÃO CIENTÍFICA, 11.; ENCONTRO LATINO AMERICANO DE PÓS-GRADUAÇÃO, 17.; ENCONTRO DE INICIAÇÃO À DOCÊNCIA, 6., 2017. Paraíba. Anais [...] Paraíba: Universidade do Vale do Paraíba, 2017. p.1-4.

GERMANO, R.H.; BARBOSA, H.P.; COSTA, R.G.; MEDEIROS, A.N.; CARVALHO, F.F.R. Avaliação da composição química e mineral de cactáceas no Semiárido paraibano. Agropecuária Técnica, Areia, v. 20, n. 1, p. $51-57,1999$.

HUNT, R. Growth analysis, individual plants. In: THOMAS, B.; MURPHY, D.J.; MURRAY, D. Encyclopedia of applied plant sciences. London: Academic, 2003. 579-588p.

INOCÊNCIO, M. F.; CARVALHO, J. G.; FURTINI NETO, A. E. Potássio, sódio e crescimento inicial de espécies florestais sob substituição de potássio por sódio. Revista Árvore, Viçosa, v.38, n.1, p.113-123, 2014. 
KÖPPEN, W. Climatologia: con un estudio de los climas de la tierra. Mexico: Fondo de Cultura Economica, 1918. $478 \mathrm{p}$.

LIMA, C.A.; FALEIRO, F.G.; JUNQUEIRA, N.T.V.; COHEN, K.O.; GUIMARÃES, T. Características físicoquímicas, polifenóis e flavonoides amarelos em frutos de espécies de pitaias comerciais e nativas do Cerrado. Revista Brasileira de Fruticultura, Jaboticabal, v.35, n.2, p.565-570, 2013.

LIMA FILHO, O. F. Distúrbios nutricionais, marcha de absorção de nutrientes, análise do crescimento e teor de esteviosídeo em estévia (Stevia rebaudiana (Bert.) Bertoni). 1995. Tese (Doutorado) - Escola Superior de Agricultura "Luiz de Queiroz", Universidade de São Paulo, Piracicaba, 1995.

LIMA-FILHO, O.F.; MALAVOLTA, E.; SENA, J.O.A.; CARNEIRO, J.W.P. Absorção e acumulação de nutrientes em estévia [Stevia rebaudiana (Bert.) Bertoni]: I. Macronutrientes. Scientia Agricola, Piracicaba, v.54, n.1/2, p.23-30, 1997.

LUDERS, L.; Mc MAHON, G. The pitaya or dragon fruit (Hylocereus undatus). Northern Territory Govermnent, 2006. Disponível em: https://dpir.nt.gov.au/_data/assets/ pdf file/0004/232933/778.pdf. Acesso em: 30 jan. 2018.

MALAVOLTA, E. Manual de nutrição mineral de plantas. São Paulo: CERES, 2006. 631p.

MARQUES, V.B.; MOREIRA, R.A.; RAMOS, J.D.; ARAÚJO, N.A.; SILVA, F.O.R. Fenologia reprodutiva de pitaia vermelha no município de Lavras, MG. Ciência Rural, Santa Maria, v.41, n.6, p.984-987, 2011.

MARQUES, V.B.; RAMOS, J.D.R.; ARAÚJO, N.A.; MOREIRA, R.A. Correlação dos fatores ambientais e o período reprodutivo da pitaia (Hylocereus undatus) em Lavras-MG. In: Congresso Brasileiro de Fruticultura, 21., 2010, Natal. Anais [...] Natal: Centro de Eventos, 2010. p.1-4.

MARSCHNER, $\mathrm{H}$. Mineral nutrition of higher plants. 3rd ed. London: Academic Press, 2012. 889 p.

MOREIRA, R.A.; CRUZ, M.C.M.; FERNANDES, D.R.; SILVA, E.B.; OLIVEIRA, J. Nutrient accumulation at the initial growth of pitaya plants according to phosphorus fertilization. Pesquisa Agropecuária Tropical, Goiânia, v.46, n.3, p.230-237, 2016.
MIZRAHI, Y.; NERD, A.; NOBEL, P.S. Cacti as crops. Horticultural Review, New York, v.18, n.1, p.291-320, 1997.

MUNIZ, J.P.O. Abelhas e a polinização da pitaya (Hylocereus spp.): implicações no vingamento, características físicas e físico-químicas do fruto. 2017. Dissertação (Mestrado em Zootecnia) - Universidade Federal do Ceará, Fortaleza, 2017.

NELDER, J.A. The fitting of a generalization of the logistic curve. Biometrics, Washington, v.17, n.1, p.89$110,1961$.

PEGORARO, R.F.; SOUZA, B.A.M.; MAIA, V.M.; AMARAL, U.; PEREIRA, M.C.T. Growth and production of irrigated 'vitória' pineapple grown in semi-arid conditions. Revista Brasileira de Fruticultura, Jaboticabal, v.36, n.3, p.693-703, 2014.

PRADO, R.M; FRANCO, C.F. Eficiência de absorção de nutrientes em mudas de goiabeiras Paluma e Século XXI, cultivadas em solução nutritiva. Revista Brasileira de Ciências Agrarias, Recife, v.2, n.4, p.275-280, 2007.

PRADO, R.M. Nutrição de plantas. São Paulo: UNESP/ FUNESP, 2008. 408 p.

RAIJ, B. Van. Fertilidade do solo e adubação. Piracicaba: Potafós, 1991. 343p.

ROZANE, D.E.; PRADO, R.de M.; NATALE, W.; FRANCO, C.F. Crescimento, teor e acúmulo de nutrientes em hipobiotos de caramboleiras, cultivados em diferentes soluções nutritiva. Revista Ceres, Viçosa, MG, v. 58 , n.3, p.366-372, 2011

ROZANE, D.E.; PRADO, R.M.; NATALE, W.ROMUALDO, L.M.; FRANCO, C.F. Caracterização biométrica e acúmulo de nutrientes em porta-enxertos de caramboleira cultivada em solução nutritiva. Revista Ciência Agronômica, Fortaleza, v.44, n.3, p.426-436, 2013.

SANTOS, V.R.; ANDRADE, I.F.; SANTIAGO, L.J.M.; LOURO, R.P. Análise ultraestrutural e anatômica do cladódio de Opuntia vulgaris (cactaceae). In: CONGRESSO 67 NACIONAL DE BOTÂNICA, 64., 2013, Belo Horizonte. Anais [...]. p.1.

SAS INSTITUTE. SAS/STAT: user's guide. Versão 12.1. Cary: SAS Institute, 2012. 
SILVA, A.C. Pitaya: melhoramento e produção de mudas. 2014. 132 f. Tese (Doutorado em Agronomia) Universidade Estadual Paulista, Faculdade de Ciências Agrárias e Veterinárias, Jaboticabal, 2014.

SILVA, A.C.C.; CAVALLARI, L.L.; SABIÃO, R.R.; MARTINS, A.B. Fenologia reprodutiva da pitaya vermelha em Jaboticabal, SP. Ciência Rural, Santa Maria, v.45, n.4, p.585-590, 2015.

SOARES, E.R.; COUTINHO, E.L.M.; RAMOS, S.B.; SILVA, M.S.; BARBOSA, J.C. Acúmulo de matéria seca e macronutrientes por cultivares de sorgo sacarino. Semina, Londrina, v. 35, n. 6, p. 3015-3030, 2014.
SYSTAT SOFTWARE. SSI. SigmaPlot. Version 11.0. 2006.

TAIZ, L.; ZEIGER, E.; MOLLER, I.M.; MURPHY, A. Fisiologia e desenvolvimento vegetal. 6.ed. Porto Alegre: Artmed, 2017. 888 p.

WELBANK, P.J. The effects of competition with Agropyron repens and of nitrogen and water supply on the nitrogen content of Impatiens parviflora. Annals of Botany, Londres, v.26, n.103, p.361-373, 1962. 